\title{
Facies Analysis and Depositional Environment of the Oligocene-Miocene Asmari Formation, Bandar Abbas Hinterland, Iran
}

\author{
Mahdi Hoseinzadeh1*, Jahanbakhsh Daneshian' ${ }^{2}$, Seyed Ali Moallemi' ${ }^{3}$, Ali Solgi ${ }^{1}$ \\ ${ }^{1}$ Department of Geology, College of Basic Science, Tehran Science and Research Branch, Islamic Azad University, \\ Tehran, Iran \\ ${ }^{2}$ Department of Geology, Faculty of Earth Science, Kharazmi University of Tehran, Tehran, Iran \\ ${ }^{3}$ Reservoir Geology Division, Exploration and Production Department, Research Institute of Petroleum Industry, \\ Tehran, Iran \\ Email: mhd hoseinzadeh@yahoo.com, daneshian@khu.ac.ir, moallemisa@ripi.ir
}

Received 3 February 2015; accepted 6 April 2015; published 9 April 2015

Copyright (C) 2015 by authors and Scientific Research Publishing Inc.

This work is licensed under the Creative Commons Attribution International License (CC BY).

http://creativecommons.org/licenses/by/4.0/

(c) (i) Open Access

\begin{abstract}
The Asmari Formation is a thick carbonate sequence of the Oligocene-Miocene in the Zagros Basin, southwest of Iran. This formation is located in Bandar Abbas and Coastal Fars regions on the following two sections: Anguro anticline (west-northwest of Bandar Abbas) and Gavbast anticline (southwest of Lar County). The Asmari Formation has diameters of 68 and $26 \mathrm{~m}$ in the Anguro and Gavbast sections, respectively. This formation is composed of limestone, dolomitic limestone and an altered form of marl. Based on the results of petrographic analyses, 7 facies were identified in the Anguro and Gavbast sections in the study region. The facies were deposited on the following 3 belts: tidal flat (MF 1 - 3), lagoon (MF 4 - 5) and open marine (MF 6, 7). According to evidence such as the gradual change of microfacies, the lack of main reef barriers, and the lack of slumping and sliding features, the Asmari Formation was formed in a marine environment of carbonate homoclinal ramp type. This environment is composed of the following two subenvironments: the inner ramp and the middle ramp. The comparison of the facies identified in the Anguro and Gavbast sections indicates that Gavbast section is mainly composed of lagoon facies. Moreover, the Anguro section demonstrates more facies diversity than Gavbast section.
\end{abstract}

\section{Keywords}

Asmari Formation, Depositional Environment, Microfacies, Ramp, Bandar Abbas Hinterland, Iran

${ }^{*}$ Corresponding author.

How to cite this paper: Hoseinzadeh, M., Daneshian, J., Moallemi, S.A. and Solgi, A. (2015) Facies Analysis and Depositional Environment of the Oligocene-Miocene Asmari Formation, Bandar Abbas Hinterland, Iran. Open Journal of Geology, 5, 175-187. http://dx.doi.org/10.4236/ojg.2015.54016 


\section{Introduction}

The Asmari Formation (the most important reservoir of Iran) is a thick carbonate sequence of the OligoceneMiocene in the Zagros Basin, southwest of Iran. The Asmari Formation at the type section consists of $314 \mathrm{~m}$ of limestone, dolomitic limestone and argillaceous limestone [1]. The Asmari Formation, at its type section, is deposited during the late Oligocene (Rupelian)-early Miocene (Burdigalian) (Figure 1). The base of the Asmari Formation varies in age. For instance, toward the coastal Fars area, it is mainly Rupelian while in the Dezful Embayment, it ranges from Rupelian to Chattian [1].

In spite of the extension of the deposits of the Asmari Formation in the Zagros Basin, these deposits have not been studied properly. In this research, numerous sections were studied for the careful examination of the Asmari Formation in the Bandar Abbas region, on the east of the coastal Fars (southwest of Lar County). Due to the lack of deposits associated with this formation in the majority of sections, the significance of this formation, and the limited spread of these deposits in the study area, the Anguro and Gavbast sections were selected (in spite of the low thickness of the Asmari Formation). The main objectives of this research were focused on 1) a description of the facies and their distribution on the Oligocene-Miocene carbonate platform, and 2) describing and interpreting the depositional environments represented by the Asmari Formation.

\section{Geological Setting}

Based on the sedimentary sequence, magmatism, metamorphism, structural setting and intensity of deformation, the Iranian Plateau has been subdivided into eight continental fragments, including Zagros, Sanandaj-Syrjan, Urumieh-Dokhtar, Central Iran, Alborz, Kopeh-Dagh, Lut, and Makran [3] (Figure 2(a)). The Zagros Basin is composed of a thick sedimentary sequence that covers the Precambrian basement formed during the Pan-African

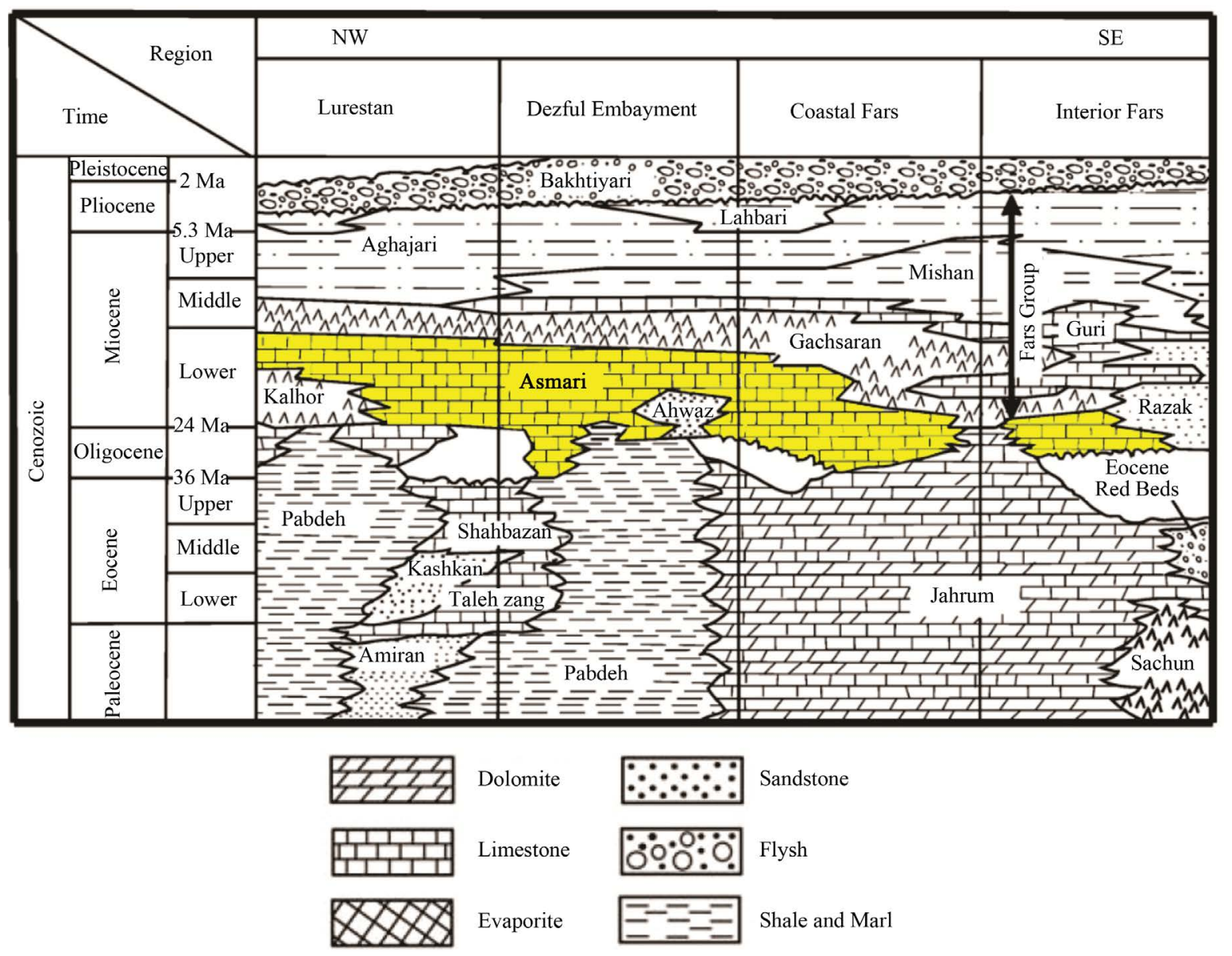

Figure 1. Cenozoic stratigraphy of the Zagros Basin, after James and Wynd (1965) [2]. 


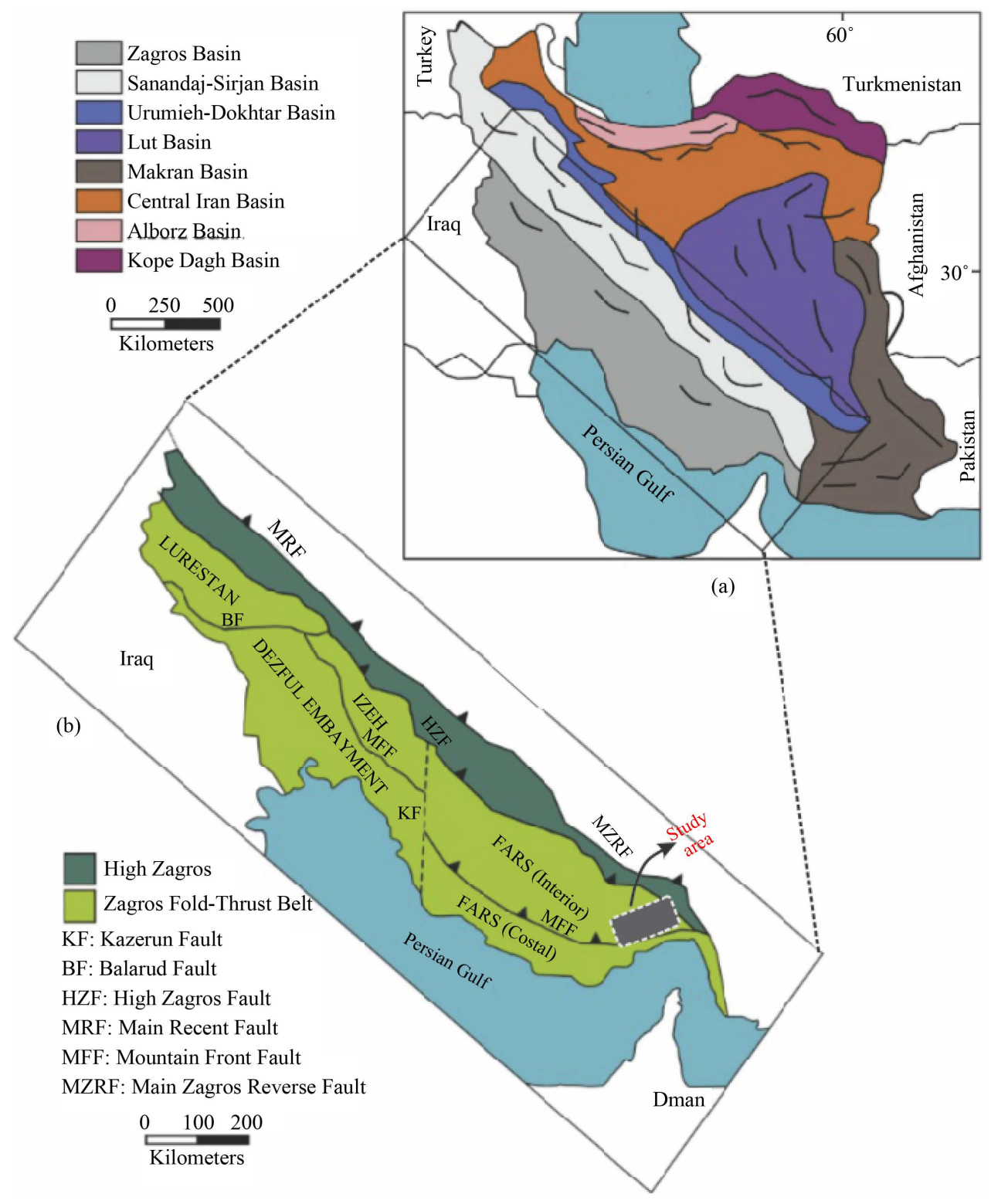

Figure 2. Location and Geological map of the study area. (a) General map of Iran showing eight geologic provinces, adapted from Lacombe et al. (2006) [17] and Mobasher and Babaie (2008) [18]; (b) Sub-divisions of the Zagros Mountains and Fars Subbasin, after Motiei (1994) [1], with situation of the study sections in Fars Province.

orogeny [4]. The total thickness of the sedimentary column deposited above the Neoproterozoic Hormuzsalt before the Neogene Zagros folding can reach over 8 - $10 \mathrm{~km}$ [5] [6]. The Zagros Basin has evolved through a number of different tectonic settings since the end of Precambrian. The basin was part of the stable Gondwana supercontinent in the Paleozoic, a passive margin in the Mesozoic, and it became a convergent orogen in the Cenozoic [7] [8]. During the Paleozoic, Iran, Turkey and the Arabian plate (which now has the Zagros Belt situated along its northeastern border) together with Afghanistan and India, made up the long, very wide and stable passive margin of Gondwana, which bordered the Paleo-Tethys Ocean to the north [9]. By the late Triassic, the Neo-Tethys Ocean had opened up between Arabia (which included the present Zagros region as its northeastern margin) and Iran, with two different sedimentary basins on both sides of the ocean [9]. The closure of the Neo-Tethys Basin, mostly during the late Cretaceous, was due to the convergence and northeast subduction of the Arabian Plate beneath the Iranian sub-plate [9]-[12]. The closure led to the emplacement of pieces of the 
Neo-Tethyan oceanic lithosphere (i.e., ophiolites) onto the northeastern margin of the Afro-Arabian plate (e.g., [13]-[15]). Continent-continent collision starting in the Cenozoic has led to the formation of the Zagros FoldThrust Belt, continued shortening of the mountain range, and creation of the Zagros foreland basin. The late Cretaceous to Miocene rocks represent deposits of the foreland basin prior to the Zagros Orogeny, and subsequent incorporation into the colliding rock sequences. This sequence unconformably overlies Jurassic to Upper Cretaceous rocks. Compressional folding began during or soon after the deposition of the Oligocene-Miocene Asmari Formation [16]. On the basis of lateral facies variations, the Zagros Fold-Thrust Belt is divided into different tectonostratigraphic domains that from NW to SE are: the Lurestan Province or Western Zagros, the Izeh Zone and Dezful Embayment or Central Zagros, and finally Fars Province or Eastern Zagros [1] (Figure 2(b)).

Also, from southwest to northeast of the Zagros Basin the following zones are distinguished: Zagros folded belt, fold and thrust belt, High Zagros and crushed zone. The Zagros Basin is also one of the most prolific oil reservoirs in the Middle East. The study area is located in the northeastern part of the Fars Interior Zone.

\section{Study Area and Methodology}

Anguro section is situated on the Anguro anticline with a length of $45 \mathrm{~km}$ and a width of $12 \mathrm{~km}$. It is located on the west-northwest of Bandar Abbas City. It has a latitude of $27^{\circ} 16^{\prime}$ and longitude of $55^{\circ} 50^{\prime}$. Gavbast section is situated on the Gavbast anticline with a length of $30 \mathrm{~km}$ and width os $7 \mathrm{~km}$. It is located on the southwest of Lar County (Fars Province). It has a latitude of $27^{\circ} 14^{\prime}$ and longitude of $53^{\circ} 52^{\prime}$. In both of the sections under study, the lower boundary of the Asmari Formation is placed on the Jahrum Formation through a paraconformity. The upper boundary is conformable with the Gachsaran Formation (Figures 3(a)-(c)). Following field inspections, 70 samples were collected from the sections of interest to study the Asmari Formation.

Thin sections of the samples were also obtained for the purpose of microscopic studies. The resulting thin sections were stained using Dickson's method [19] and alizarine red to spot the calcite and dolomite contents. In this study, the Dunham classification was used for the classification of carbonate rocks [20]. Facies were also classified based on Fugel's standard facies [21] and sedimentary environments were described based on Buxton and Pedley classification [22].

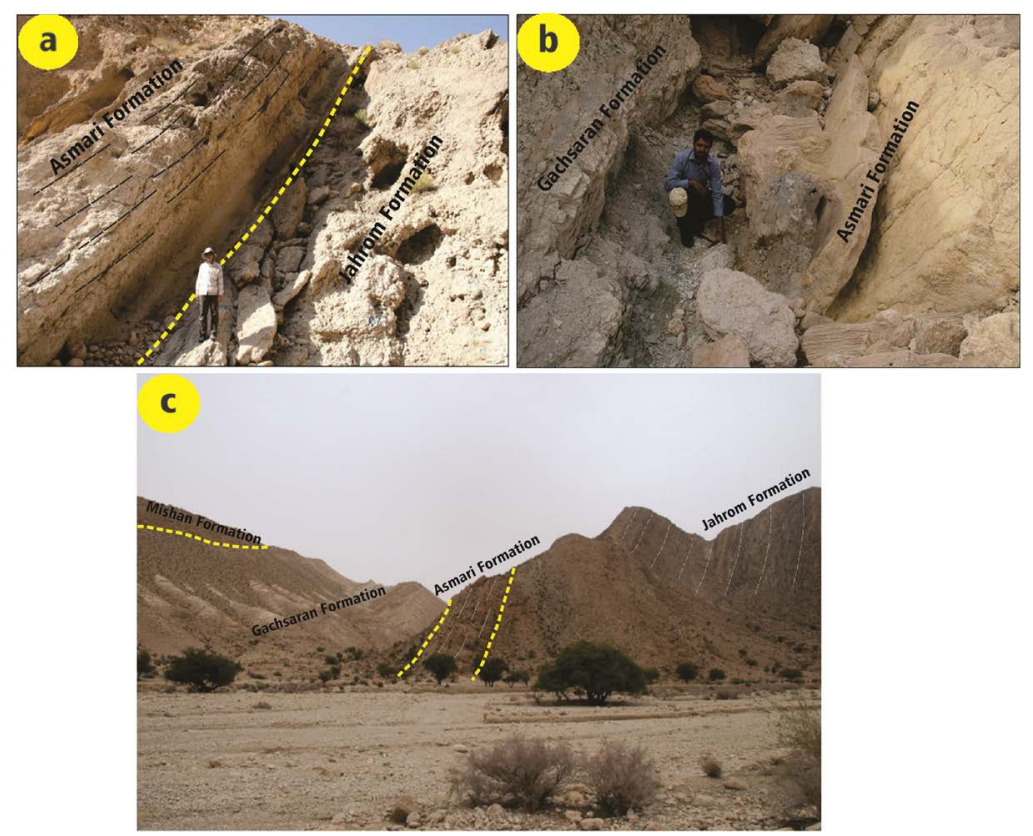

Figure 3. Field photographs showing: (a) A west view of the Anguro Section (lower boundary of the Asmari Formation with Jahrum Formation); (b) Upper boundary of the Asmari Formation with Gachsaran Formation is identified with paleosoil horizon in Anguro Section; (c) A east view of the Gavbast Section (Lower boundary and upper boundary of the Asmari Formation with Jahrum Formation and Gachsaran Formation respectively). 


\section{Previous Works}

Interest in the study of the paleontology, stratigraphy, and sedimentary environment of the Asmari Formation has been largely motivated by the exploration for oil and gas, because it contains more than 90\% of Iran's oil. The Asmari Formation was adopted after the Asmari anticline located in the northern Dezful Embayment and was referred to a sequence of Cretaceouse-Eocene in age [23]. The Asmari Formation was measured and defined as an Oligocene nummulitic limestone by Richardson [24] and described by Thomas [25] as an Oligocene-Miocene carbonate interval. James and Wynd [2] summarized previous viewpoints and finally formally defined the Asmari Formation. Recently, the studies of biostratigraphy, depositional environment and sequence stratigraphy have been undertaken by Seyrafian et al. [26], Seyrafian [27], Seyrafian and Mojikhalifeh [28], Vaziri-Moghaddam et al. [29], Amirshahkarami et al. [30] and Hakimzadeh and Seyrafian [31]. Ehrenberg et al. [32] and Laursen et al. [33] examined the Asmari Formation based on Sr isotope stratigraphyand revised age ranges mostly for the lower and middle parts of the Asmari Formation. Moreover, salinity changes duringthe late Oligocene to early Miocene for deposition of the Asmari Formation have been described by Mossadegh et al. [34].

\section{Lithology}

According to the results of field examinations of the study area, the thickness of the Asmari Formation increases relatively from the north to the south in the Bandar Abbas region. Therefore, the thickness of this formation in the Anguro and Gavbast anticlines is approximately 68 and $26 \mathrm{~m}$, respectively. A total of 59 samples were obtained from the deposits of the Asmari Formation which were located in the Anguro section with a thickness of $68 \mathrm{~m}$. This formation forms the heights and resistant areas due to its limestone lithology and high resistance to erosive factors. The lower boundary of the Asmari Formation is placed on top of shallow limestones of the upper part of the Jahrum Formation through a paraconformity (as a result of the absence of assemblage zone no. 58). The Asmari Formation contained within the Anguro section includes sequences of limestone, dolomitic limestone, and an alternation of marl and gray limestone. At the base of the Asmari Formation located on this section, gray limestones enriched with large benthic foraminifera accumulations (such as Nummulites intermedius-fichteli) were found next to other skeletal components (such as bivalves and echinoid debris) (Figure 4).

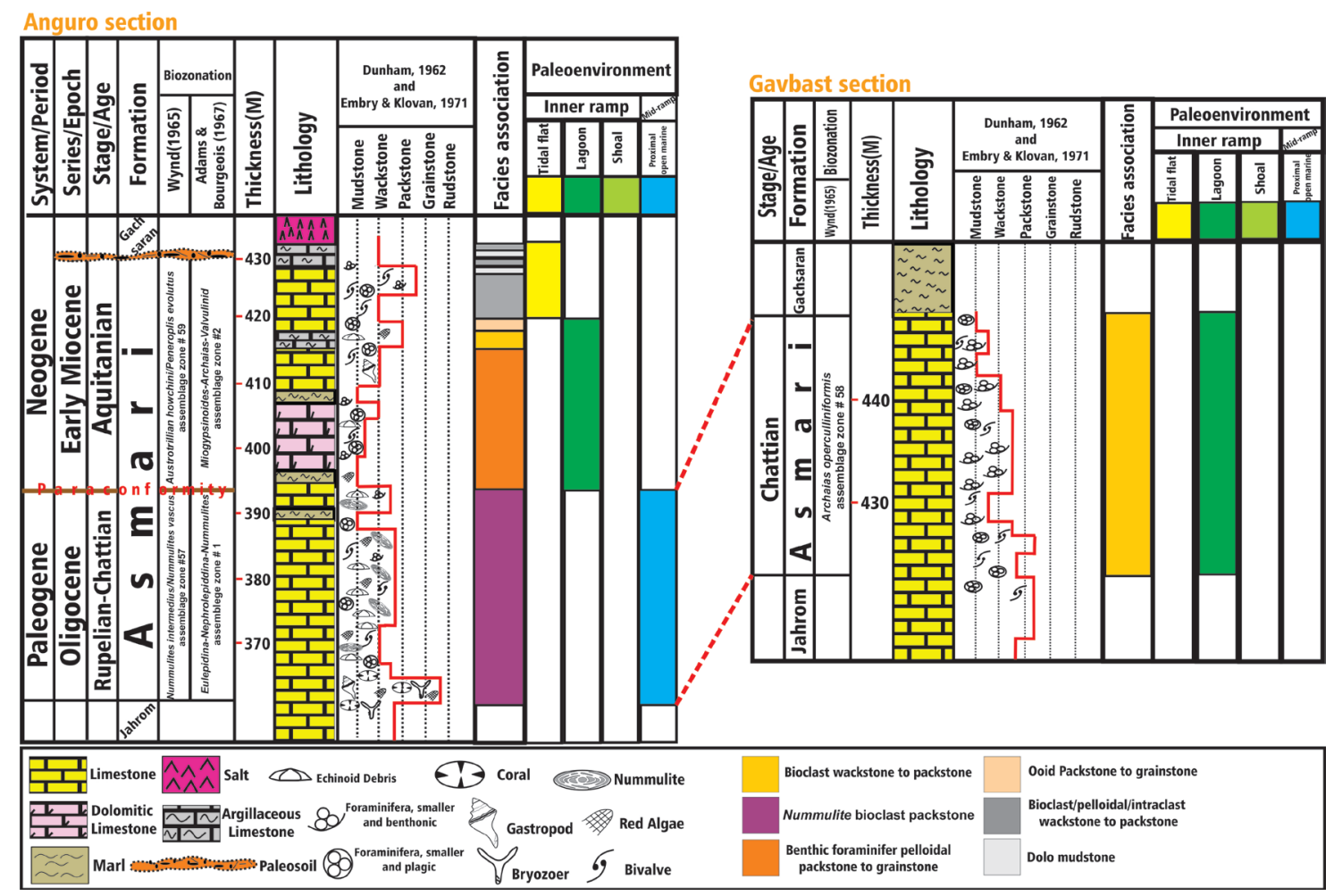

Figure 4. Faunal distribution, biozonation and lithology of the Asmari Formation at Anguroan Gavbast sections. 
The upper parts of the Asmari Formation contain sequences of thick dolomitic limestone and an alternation of limestone and marl. Large benthic foraminifera and bivalve fossils are also abundant in this section. There are also numerous fractures in this formation. The upper boundary of the Asmari Formation is conformable with the Gachsaran Formation. The evaporative Gachsaran Formation contains sequences of evaporate rocks located on the limestones of the Asmari Formation. The Gachsaran Formation demonstrates a milder topography as compared to the heights and walls formed by the Asmari Formation. That part of the Asmari Formation which is located on the Gavbast section has a total thickness of $26 \mathrm{~m}$ (Figure 4). This formation in this section was fully examined and 11 samples were obtained from it. Paleontological studies suggest that the lower boundary of the Asmari Formation is placed on the shallow limestones of the upper section of the Jahrum Formation. The part of the formation that lies on this section includes sequences of gray limestone. At the base of the section, the Asmari Formation includes gray limestone enriched with large benthic foraminifera accumulations (such as $A r-$ chaias operculiniformis) and skeletal components (such as bivalves and echinoid debris). The upper parts of the formation embrace sequences of thick limestone as well as plenty of large benthic foraminifera and bivalve fossils. In the study area, the Gachsaran Formation lies on the Asmari Formation with in the conformable. It also demonstrates a milder topography as compared to the heights and walls formed by the Asmari Formation.

\section{Biostratigraphy}

Biostratigraphic criteria of the Asmari Formation were established by Wynd [35] (Table 1) and reviewed by Adams and Bourgeois [36] (Table 2) in unpublished reports only. Based on the foraminiferal assemblages, the Asmari Formation is divided into lower, middle, and upper units. From base to top, three foraminiferal assemblages were recognized in the study area:

1) Assemblage $l$ is characterized by the presence of Rotalia viennotti, Ditrupa sp., Planorbulina sp., Spirolina cylindracea, Austrotrillina asmariensis, Paragloborotalia spp. and coral and echinoid debris. This microfauna correspond to the Nummulites intermedius-Nummulites vascus Assemblage zone of Wynd [35] and Eulepidina-

Table 1. Biozonation of the Asmari Formation, Wynd (1965).

\begin{tabular}{|c|c|c|}
\hline Formation & Biozone & Age \\
\hline $\begin{array}{l}\text { Basal limestones of the Asmari } \\
\text { Formation }\end{array}$ & 56. Lepidocyclina-Opercolina-Ditropaassemblage zone & Oligocene? \\
\hline Lower Part of Asmari Formation & $\begin{array}{l}\text { 57. Nummulites intermedius-Nummulites vascus } \\
\text { assemblage zone }\end{array}$ & Oligocene \\
\hline Lower Part of Asmari Formation & 58. Archaias operculiniformis totalrange zone Oligocene & \\
\hline $\begin{array}{l}\text { Middle Part of Asmari Formation } \\
\text { - Lowest Levels of the } \\
\text { Gachsaran Formation }\end{array}$ & $\begin{array}{l}\text { 59. Austrotrillina howchini-Peneroplis evolutus } \\
\text { assemblage zone } \\
60 \text {. Austrotrillina howchini-Peneroplis evolutus } \\
\text { (Gachsaran Fm.) }\end{array}$ & Lower Miocene (Aquitanian) \\
\hline $\begin{array}{l}\text { Upper Part of Asmari Formation-I } \\
\text { Parts of the Gachsaran and } \\
\text { Razak Formations }\end{array}$ & 61,62 . Borelis melo curdica zone & Lower Miocene (Burdigalian) \\
\hline Formation & Biozone & Age \\
\hline Upper Part of Asmari Formation & $\begin{array}{l}\text { 1. Borelis melo group-Meandropsin iranica Assemblage } \\
\text { Zone }\end{array}$ & Early Miocene (Burdigalian) \\
\hline Middle Part of Asmari Formation & $\begin{array}{l}\text { 2. Miogypsinoides-Archaias-Valvulina Zone } \\
\text { 2a. Elphidium sp. 14-Miogypsina Assemblage Subzone } \\
\text { 2b. Archaias Asmaricus-Archaias hensoni Assemblage Sub- } \\
\text { zone }\end{array}$ & Early Miocene (Aquitanian) \\
\hline Lower Part of Asmari Formation & 3. Eulipidina-Nephrolepidina-Nummulites Assemblage zone & Oligocene \\
\hline Base of the Asmari Formation & 4. Globigerina spp. Assemblage Zone (Wynd, 1965) & Oligocene \\
\hline Jahrom Formation & 5. Nummulites spp. Discocyclina spp. Assemblage Zone & Late Eocene (Probably) \\
\hline Jahrom Formation & 6. Coskinolina-Rhapydionina Assemblage Zone & Middle Eocene (Probably) \\
\hline
\end{tabular}


Nephrolepidina-Nummulites Assemblage Zone of Adams and Bourgeois [36]. The faunal assemblage of this zone suggests a Rupelian-Chattian age.

2) Assemblage 11 is characterized by the presence of Paragloborotalia spp., Pyrgo spp., Triloculina sp., Russella spp., Quinqueloculina spp., Praerhapydionina delicata, Textularia spp., Elphidium spp., Valvulina spp., Penarchaias glynnjonesi, Triloculina tricarinata, Austrotrillina asmariensis, Austrotrillina sp., Schlum bergerina sp. Archaias operculiniformis, Archaias sp., Peneroplis thomasi, Peneroplis evolutus, Peneroplis sp., Spirolina spp., Dendritina rangi. This microfauna correspond to the Archaias operculiniformis total range zone of Wynd [35] and Eulepidina-Nephrolepidina-Nummulites Assemblage Zone of Adams and Bourgeois [36]. The faunal assemblage of this zone suggests a Chattian age.

3) Assemblage 111 is characterized by the presence of Dendritina rangi, Spirolina sp., Peneroplis sp., Archaias sp., Discorbis sp., Miliolids, Globorotalia spp. and Asterigerina rotula. This microfauna correspond to the Austrotrillina howchini-Peneroplis evolutus assemblage zone of Wynd [35] and Miogypsinoides-Archaias-Valvulinid Assemblage Zone of Adams and Bourgeois [36]. The faunal assemblage of this zone suggests a Aquitanian age.

\section{Facies Description and Depositional Environment}

Seven carbonate sedimentary facies were recognized for the Asmari Formation in the study area. These facies are related to three depositional settings (tidal flat, lagoon and open marine) of inner and middle portions of a carbonate platform.

\subsection{Tidal Flat Facies Association}

MF 1: Dolo Mudstone

This microfacies has been observed in the upper part of the Asmari Formation. The MF 1 consists of dolomicrite with fine dolomite crystals 5 to $16 \mu \mathrm{m}$ (Figure 5(a)). Bioturbation is also common (Figure 5(b)). There is no

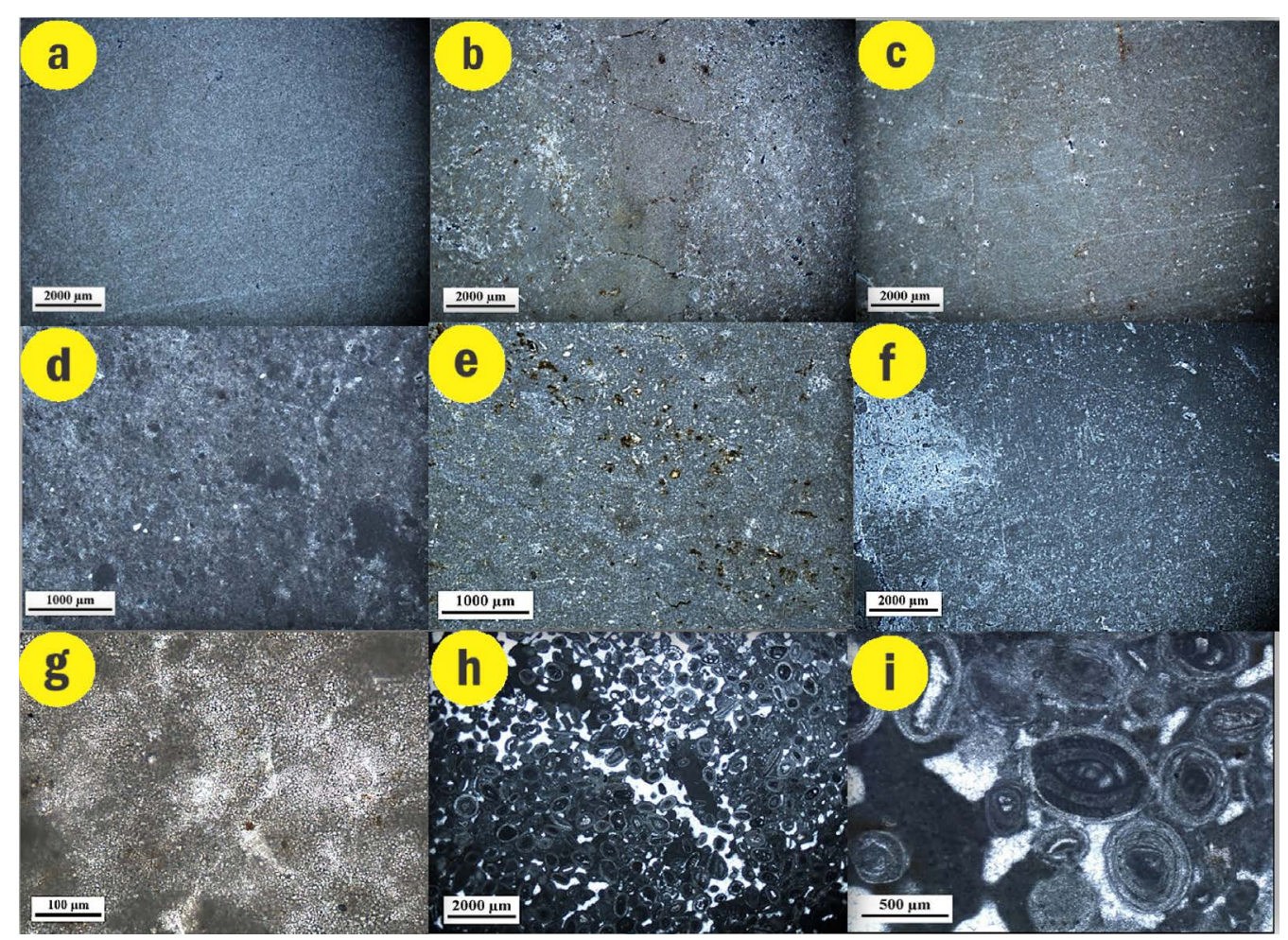

Figure 5. Photomicrographs showing: (a) Dolomudstone (XPL); (b) Bioturbation; (c) Silt-sized quartz grain scattered in matrix (XPL); (d) Dolo intraclast wackestone with silt-sized quartz grains; (e) Dolo peloid intraclast wackestone with silt-sized quartz grains (XPL); (f) Bioturbation (XPL); (g) Aggradational neomorphism in dolomicrite forming dolomicrosparite; (h) Ooid packstone to grainstone (PPL); (i) Milliolides as a core of a surficial ooid (PPL). 
bioclast in this microfacies. Silt-sized quartz grains are scattered in the dolomicrite matrix (<10\%) (Figure 5(c)). Based on the presence of dolomicrite, detrital quartz grains, bioturbation, and the lack of bioclasts and comparison to the standard microfacies of Flugel [21], it can be concluded that microfacies MF 1 has been deposited in supratidal to upper intertidal environment. This microfacies is equivalent to RMF 22 of Flugel [21] and Facies Belt 1 of Buxton \& Pedley’sclassification [22].

\subsection{MF 2: Bioclast/Pelloid/Intraclast Wackestone}

This microfacies consists of a wackestone with intraclasts (10\%), peloid (7\%) and bioclasts (Miliolides) (5\%). Silt-sized grains of quartz are scattered in the matrix (Figure 5(d) and Figure 5(e)). This microfacies is mostly dolomitized. Bioturbation (Figure 5(f)) and neomorphism is the common diagenetic processes observed. Aggradational neomorphism of dolomicrite to dolomicro sparite is also common (Figure 5(g)). Based on the presence of carbonate mud, detrital quartz grains, bioturbation, and vertical relationship with tidal flat facies, and comparison to standard microfacies of Flugel [21], it can be concluded that the MF 2 has been deposited in the lower part of intertidal environment. Presence of intraclasts indicates high energy conditions. This microfacies is equivalent to the RMF-24 of Flugel [21].

\subsection{MF 3: Ooid Packstone to Grainstone}

The texture of this microfacies varies from packstone to grainstone, and Ooid is the main allochem of this microfacies. Skeletal debris are Miliolides. Benthic foraminifera like Peneroplis sp., Peneroplis evolutus archaias sp., Austrotrillina howchini and bivalve debris are present. Superficial and two layer Ooids are well sorted. Lagoonal bioclasts formed the core of the Ooids (Figure 5(h) and Figure 5(i)). The presence of well-sorted, superficial, fine grained $(>0.5 \mathrm{~mm}$ ) Ooids, lagoonal fauna as Ooid cores, the presence of grain-supported texture, and the vertical change of this microfacies to a tidal flat microfacies (MF 1 and MF 2) indicate deposition of MF 3 in a tidal channel environment with medium to high energy condition [37].

\subsection{Lagoon Facies Association}

\section{MF 4: Bioclast Wackestone to Packstone}

The MF 4 microfaciesis characterized by a wackestone to packstone texture. The amount of allochems varies from 30\% to 50\%. The main allochems of this microfacies are bioclasts (Figure 6(a)). Different types of bioclasts including: Quinqueloculina spp., Pyrgo spp., Triloculina tricarinata, Spirolina spp., Triloculina sp., Peneroplis evolutus, Peneroplis thomasi, Peneroplis planatus, Austrotrillina paucialveolata, Dendritina rangi (small benthic foraminifera), Lithophyllum sp., Lithothamnium sp., Lithoporella sp. (Red Algae), coral debris, Ditrupa sp., echinoid debris, bivalve debris, ostracod shells, Textularia spp., Russella spp., Asterigerina rotula, Elphidium sp.1, Ammonia beccari, Austrotrillina sp., Archaias sp., Peneroplis sp., Spirolina cylindracea, Austrotrillina asmariensis, Archaias kirkukensis (large benthic foraminifera) are present in this microfacies. Peloid is a subordinate nonskeletal allochems. Bioturbation (Figure 6(b)) and dolomitization are diagenetic processes which affected this microfacies. Dolomitization may be assumed fabric-selective as shown by the micritic matrix that was dolomitized while the allochems remained calcareous (Figure 6(c)). Textural characteristics, abundant porcelanaceous foraminifera (such as Miliolids), red algae, and benthic foraminifera, peloids, the presence of lime mud and bioturbation indicates high-energy lagoon near tidal flat [29]. Mixing of porcelanaceous foraminifera with open marine fauna like echinoids and reworked Nummulites (hyaline test) indicates that these sediments have been deposited in a lagoon attached to open marine waters by a tidal channel. This microfacies is equivalent to the RMF-20 of Flugel [21] and facies belt 2 of Buxton \& Pedley [22]. Shallow depth and medium to low energy and presence in the photic zone is the characteristic of this environment. Some porcelanaceous perforate foraminifera (Peneroplis and Archaias) live in recent tropical and subtropical shallow water environment [38].

\subsection{MF 5: Benthic Foraminifera Pelloidal Packstone to Grainstone}

This microfacies is grain-supported with the texture of packstone (Figure 6(d)) to grainstone (Figure 6(e)). It consists of abundant porcelanaceous foraminifera like Triloculina trigonula, Spiroloculina spp., Pyrgo spp., Russella spp., Spirolina spp., Bigenerina sp., Triloculina sp., Triloculina tricarinata, Archaias operculiniformis, Elphidium sp.1, Ammonia beccari, Austrotrillina paucialveolata, Austrotrillina sp., Archaias sp., Peneroplis sp., 


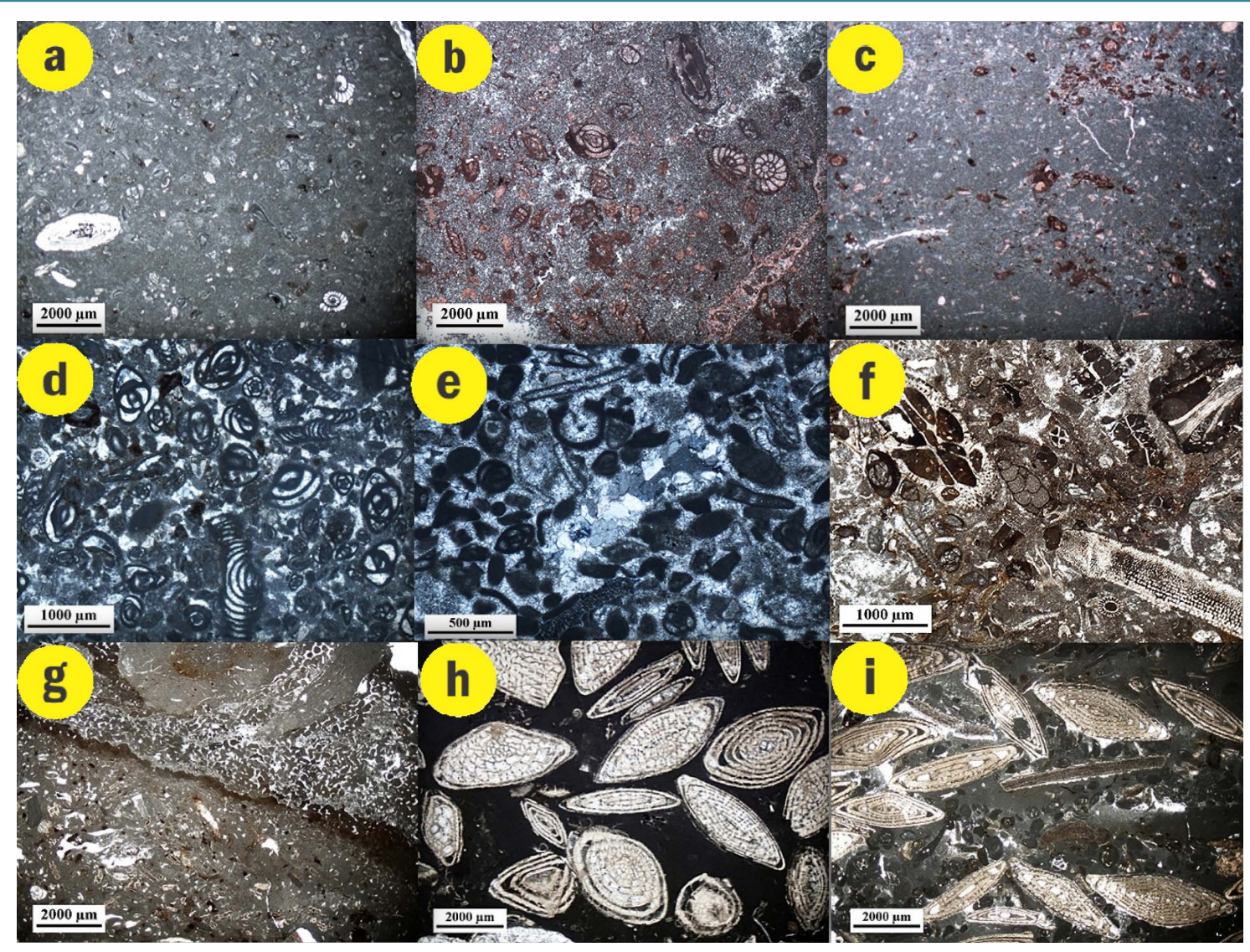

Figure 6. Photomicrographs showing: (a) Bioclast wackestone with lagoonal benthic foraminifera. Nummulites are also available (PPL); (b) Dolomitization. The matrix is dolomitized while allochems remains calcareous (PPL); (c) Bioturbatoin (PPL); (d) Benthic foraminifer pelloidal packstone (PPL); (e) Benthic foraminifer pelloidal grainstone. (PPL); (f) Bioclast echinoid packstone (PPL); (g) Bioclast coral rudstone (PPL); (h) and (i) Nummulites bioclast packstone (PPL).

Peneroplis planatus, Peneroplis evolutus, Peneroplis thomasi, Rotalia viennotti, Meandropsina iranica, Archaias kirkukensis, and non-foraminifera fossils like red algae (Lithophyllum sp. and Lithoporella sp.), bryozoans (Tubucellaria spp.), echinoids, trace fossils (Faverina asamarica), and peloids (Figure 6(e)). The amount of allochems ranges between $40 \%$ to $60 \%$. Bioturbation, micritization (Figure 6(e)) and dolomitization are the main diagenetic features of this microfacies. Isopachous rim cement is present in grainstone texture. The presence of benthic foraminifera with porcelanaceous test, peloid, bioturbation and micritization indicates that the microfacieshas been deposited in the lagoon [39] [40]. The faunal association characterizes an inner part of the platform [41]. The packstone to grainstone texture and presence of cement indicates deposition in shallow water depth above fair-weather Wave base, with medium to high energy conditions [21], wide variety of fauna, the presence of stenohaline fauna (Echinoids and bivalve) and the mixing with porcelanous foraminifera indicate that this sediment have been deposited in an open lagoon environment with normal salinity. The MF 5 is equivalent to the RMF 20 and standard facies belt 2 [22]. The main characteristics of this environment are medium to low energy in the photic zone [21].

\subsection{Open Marine Facies Association}

MF 6: Bioclast (Coral) Echinoid Packstone to Rudstone

This microfacies is characterized by packstone to rudstone texture and consists of large fragments of fossils ( $>2$ $\mathrm{mm}$ ) like corals, echinoids, bivalve, gastropods, and bryozoan especially (Tubucellaria spp.) (Figure 6(f) and Figure $6(\mathrm{~g})$ ). The amount of large fragments varies from $10 \%$ to $20 \%$. Subordinate bioclasts with the amount $30 \%-50 \%$ are present. Sorting is poor to medium. Syntaxial cement around echinoid debris are abundant. 
The wide variety of marine fauna and microfauna (corals, echinoids, bivalve, and bryozoan (Tubucellaria spp.)) suggests deposition in open and oxygenate marine conditions, perhaps above the storm wave base (cf. [42]). The MF 6 microfacies is equivalent to RMF-7 of Flugel [21] and compares to the model of Buxton \& Padley [22]. It should be equivalent to facies belt 5, deposited in mid ramp environment.

\subsection{MF 7: Nummulite Bioclast Packstone}

This grain-supported microfacies with packstone fabric mainly consists of bioclasts and Nummulites with the amounts of $30 \%$ to $50 \%$. The main fossils present are Nummulites fichteli, Nummulites intermedius, Nummulites sp. and with a lower amount, Spirolina spp., Triloculina sp., Paragloborotalia spp., Peneroplis sp., Peneroplis planatus, Peneroplis evolutus, Peneroplis thomasi, Archaias kirkukensis and non-foraminifera are red algae including Lithophyllum sp., Lithothamnium sp., Lithoporella sp. However bioclasts of macro and microfossils debris including Ditrupa sp., echinoid debris, Faverina asmarica, bivalve debris, ostracod shells are also observed. Bioturbation is also common (Figure 6(h) and Figure 6(i)). Sorting is poor to medium.

The presence of hyaline test of microfauna like Nummulites and also stenohaline fauna such as echinoids, indicates deposition in a proximal open marine environment. Abundance and size of the Nummulites are good indicators of the depositional environments [43]. According to Racey [43], elongate and large Nummulites have occurred offshore, in deeper water conditions with respect to other types of Nummulites, indicating increase in accommodation space. This microfacies is equivalent to the RMF-13 of Flugel [21] and facies belt 5 of Buxton \& Pedley [22]. The association of red algae and larger benthic foraminifera is known to inhabit the Oligo-photic zone of the middle ramp environment [39] [41] [44] [45].

\section{Facies Association and Depositional Model}

The results of the microfacies analysis indicate seven types of microfacies deposited in three standard facies belt: tidal flat (MF 1 - 3), Lagoon (MF 4, 5) and proximal open marine environment (MF 6, 7). A homoclinal ramp is proposed for the studied section composed of inner and mid-ramp, the inner ramp including tidal flat and lagoon subenvironments. This latter is indicated by the presence of dolomudstone, bioclast/peloid/intraclast wackestone to packstone, and ooid packstone/grainstone facies, while the lagoon by bioclast wackestone/packstone and benthic foraminifer peloidal packstone/grainstone (Figure 7).

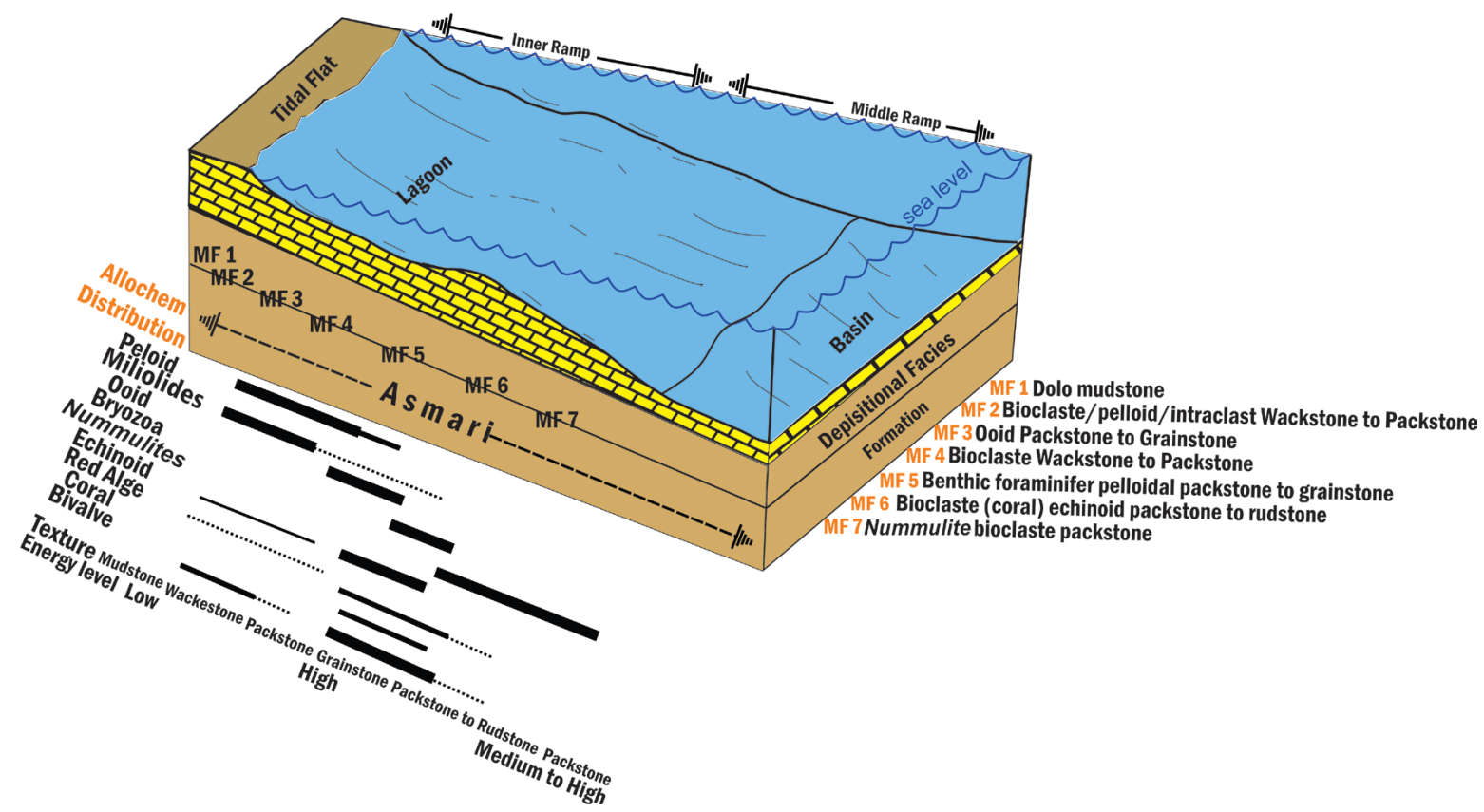

Figure 7. Schematic block diagram of depositional environment of the Asmari Formation in the Bandar Abbas area. Lateral distribution of microfacies in the sedimentary model, petrographic characteristics, and main carbonate particles of various facies are shown. 
The main components of these subenvironments are bioclasts of milliolids, Peneroplis sp., Peneroplis evolutus, Archaias sp., and Austrotrillina howchini, peloid, superficial Ooids, dolomicrite and detrital quartz. The mid ramp encompasses proximal open marine subenvironment as indicated by the bioclast (coral) echinoid packstone to rudstone, and Nummulite bioclast packstone facies. Main constituents include coral, bivalve, and gastropod debris, along with bryozoans, especially (Tubucellaria spp.). The presence of hyaline tests of microfauna like Nummulites as also stenohaline fauna, such as echinoids, indicates the deposition in a proximal open marine subenvironment (Figure 7). Previous studies considered different depositional platform types for the Asmari Formation. Some authors (e.g., [27] [29] [46]) assumed the depositional environment of the Asmari Formation as shelf, while other workers (e.g., [29] [30] [39] [47]-[49]) considered it as a carbonate ramp.

The results presented in the present report, based on the gradual changes of microfacies, the lack of main barrier reefs, and the slumping and sliding features, clearly suggest that the Asmari Formation has been deposited on a homoclinal ramp environment. Our results are in complete concordance with Pedley [50] who has proposed that during the Oligocene-Miocene, distally steepened and homoclinal ramps were widespread in Mediterranean areas.

\section{Conclusions}

The thickness of the Asmari Formation increases from north to south in the Bandar Abbas area. In this area, this formation thickness is 68 and $26 \mathrm{~m}$ respectively in the Anguro and Gavbast sections.

The Asmari Formation in the Gavbast section has been deposited in an inner ramp. Fossil contents indicate that the lower contact of the Asmari Formation is with shallow marine carbonates of the Jahrum Formation. The upper contact of the Asmari Formation with the Gachsaran Formation is a disconformity.

The Asmari Formation contained within the Anguro section includes sequences of limestone, dolomitic limestone, and an alternation of marl and gray limestone.

In the Anguro and Gavbast sections, seven types of microfacies have been identified. These microfacies are interpreted as have been deposited in 3 microfacies belts, including tidal flat (MF 1 - 3), lagoon (MF 4, 5) and proximal open marine (MF 6, 7) environments. Gradual transition between microfacies, the lack of main barrier reef, and sliding and slumping features indicate the Asmari Formation has been deposited in a homoclinal ramp. Two subenvironments have been identified: inner ramp and mid-ramp. The lagoonal microfacies is the more abundant, followed by lagoon facies belt, the tidal flat (inner ramp) and proximal open marine facies belt are developed respectively.

\section{Acknowledgements}

Research Institute of Petroleum Industry for permission for publication of this paper. The authors also appreciate Alireza Shakeri, Mehran Moradpour, Somayeh Parham, Mehdi Hadi, Rakhsahndeh Abbasi, Zahra Ahmadi, Morteza Fakhr Rahimiyan, Afshin Zohdi and Saeed Monibi for their cooperation during the project.

\section{References}

[1] Motiei, H. (1994) Geology of Iran: Stratigraphy of Zagros. Geological Survey of Iran Publication, Tehran, 583.

[2] James, G.A. and Wynd, J.G. (1965) Stratigraphic Nomenclature of Iranian Oil Consortium Agreement Area. AAPG Bulletin, 49, 2182-2245.

[3] Heydari, E., Hassanzadeh, J., Wade, W.J. and Ghazi, A.M. (2003) Permian-Triassic Boundary Interval in the Abadeh Section of Iran with Implications for Mass Extinction, Part 1-Sedimentology. Paleogeography, Paleoclimatology, Paleoecology, 193, 405-423. http://dx.doi.org/10.1016/S0031-0182(03)00258-X

[4] Al-Husseini, M.I. (2000) Origin of the Arabian Plate Structures: Amar Collision and Najd Rift. Geo Arabia, 5, 527-542.

[5] Alavi, M. (2004) Regional Stratigraphy of the Zagros Fold-Thrust Belt of Iran and Its Proforel and Evolution. American Journal of Sciences, 304, 1-20. http://dx.doi.org/10.2475/ajs.304.1.1

[6] Sherkati, S. and Letouzey, J. (2004) Variation of Structural Style and Basin Evolution in the Central Zagros (Izeh Zone and Dezful Embayment), Iran. Marine and Petroleum Geology, 21, 535-554. http://dx.doi.org/10.1016/j.marpetgeo.2004.01.007

[7] Bahroudi, A. and Koyi, H.A. (2004) Tectono-Sedimentary Framework of the Gachsaran Formation in the Zagros Foreland Basin. Marine and Petroleum Geology, 21, 1295-1310. http://dx.doi.org/10.1016/j.marpetgeo.2004.09.001 
[8] Sahraeyan, M. and Bahrami, M. (2012) Petrography and Provenance of Sandstones from the Aghajari Formation, Folded Zagros Zone, Southwestern Iran. International Journal of Basic and Applied Sciences, 1, 283-298. http://dx.doi.org/10.14419/ijbas.v1i3.157

[9] Berberian, M. and King, G.C.P. (1981) Towards a Paleogeography and Tectonic Evolution of Iran. Canadian Journal of Earth Sciences, 18, 210-265. http://dx.doi.org/10.1139/e81-019

[10] Berberian, M. (1995) Master "Blind” Thrust Faults Hidden under the Zagros Folds: Active Basement Tectonics and Surface Morphotectonics. Tectonophysics, 241, 193-224. http://dx.doi.org/10.1016/0040-1951(94)00185-C

[11] Beydoun, Z.R., Hughes Clarke, M.W. and Stoneley, R. (1992) Petroleum in the Zagros Basin: A Late Tertiary Foreland Basin Overprinted onto the Outer Edge of a Vast Hydrocarbon-Rich Paleozoic-Mesozoic Passive Margin Shelf. In: Macqueen, R.W. and Leckie, D.A., Eds., Foreland Basins and Fold Belts, Vol. 55, AAPG Memoir, Tulsa, 309-339.

[12] Stoneley, R. (1981) The Geology of the Kuh-e Dalneshin Area of Southern Iran, and Its Bearing on the Evolution of Southern Tethys. Journal of the Geological Society, 138, 509-526. http://dx.doi.org/10.1144/gsjgs.138.5.0509

[13] Babaei, A., Babaie, H.A. and Arvin, M. (2005) Tectonic Evolution of the Neyrizophiolite, Iran: An Accretionary Prism Model. Ofioliti, 30, 65-74.

[14] Babaie, H.A., Babaei, A., Ghazi, A.M. and Arvin, M. (2006) Geochemical, ${ }^{40} \mathrm{Ar} /{ }^{39} \mathrm{Ar}$ Age, and Isotopic Data for Crustal Rocks of the Neyriz ophiolite, Iran. Canadian Journal of Earth Sciences, 43, 57-70. http://dx.doi.org/10.1139/e05-111

[15] Babaie, H.A., Ghazi, A.M., Babaei, A., La Tour, T.E. and Hassanipak, A.A. (2001) Geochemistry of Arc Volcanic Rocks of the Zagros Crust Zone, Neyriz, Iran. Journal of Asian Earth Sciences, 19, 61-76. http://dx.doi.org/10.1016/S1367-9120(00)00012-2

[16] Sepehr, M. and Cosgrove, J.W. (2004) Structural Framework of the Zagros Fold-Thrust Belt, Iran. Marine and Petroleum Geology, 21, 829-843. http://dx.doi.org/10.1016/j.marpetgeo.2003.07.006

[17] Lacombe, O., Mouthereau, F., Kargar, S. and Meyer, B. (2006) Late Cenozoic and Modern Stress Fields in the Western Fars (Iran): Implications for the Tectonic and Kinematic Evolution of Central Zagros. Tectonics, 25, TC1003. http://dx.doi.org/10.1029/2005TC001831

[18] Mobasher, K. and Babaie, H.A. (2008) Kinematic Significance of Fold- and Fault-Related Fracture Systems in the Zagros Mountains, Southern Iran. Tectonophysics, 451, 156-169. http://dx.doi.org/10.1016/j.tecto.2007.11.060

[19] Dickson, J.A.D. (1965) A Modified Staining Technique for Carbonate in Thin Section. Nature, 205, 587. http://dx.doi.org/10.1038/205587a0

[20] Dunham, R.J. (1962) Classification of Carbonate Rocks According to Depositional Texture. American Association of Petroleum Geologist Memoirs, 1, 108-121.

[21] Flugel, E. (2010) Microfacies of Carbonate Rocks: Analysis, Interpretation and Application. 2nd Edition, SpringerVerlag, Berlin, New York.

[22] Buxton, M.W.N. and Pedley, H.M. (1989) A Standardized Model for Tethyan Tertiary Carbonates Ramps. Journal of the Geological Society, 146, 746-748. http://dx.doi.org/10.1144/gsjgs.146.5.0746

[23] Busk, H.G. and Mayo, H.T. (1918) Some Notes on the Geology of the Persian Oilfields. Journal of the Institute of Petroleum Technology, 5, 5-26.

[24] Richardson, R.K. (1924) The Geology and Oil Measures of Southwest Persia. Journal of the Institute of Petroleum Technology, 1, 256-283.

[25] Thomas, N.A. (1948) The Asmari Limestone of Southwest Iran. National Iranian Oil Company, Report 706, Unpublished.

[26] Seyrafian, A., Vaziri-Moghaddam, H. and Torabi, H. (1996) Biostratigraphy of the Asmari Formation, Burujen Area, Iran. Journal of Sciences, 7, 31-48.

[27] Seyrafian, A. (2000) Microfacies and Depositional Environments of the Asmari Formation, at Dehdez Area (a Correlation across Central Zagros Basin). Carbonates and Evaporites, 15, 121-129. http://dx.doi.org/10.1007/BF03175819

[28] Seyrafian, A. and Mojikhalifeh, A. (2005) Biostratigraphy of the Late Paleogene-Early Neogene Succession, NorthCentral Border of Persian Gulf, Iran. Carbonates and Evaporites, 20, 91-97. http://dx.doi.org/10.1007/BF03175452

[29] Vaziri-Moghaddam, H., Kimiagari, M. and Taheri, A. (2006) Depositional Environment and Sequence Stratigraphy of the Oligocene-Miocene Asmari Formation in SW Iran, Lali Area. Facies, 52, 41-51. http://dx.doi.org/10.1007/s10347-005-0018-0

[30] Amirshahkarami, M., Vaziri-Moghaddam, H. and Taheri, A. (2007) Sedimentary Facies and Sequence Stratigraphy of the Asmari Formation at Chaman-Bolbol, Zagros Basin, Iran. Journal of Asian Earth Sciences, 29, 947-959. 
http://dx.doi.org/10.1016/j.jseaes.2006.06.008

[31] Hakimzadeh, S. and Seyrafian, A. (2008) Late Oligocene-Early Miocene Benthic Foraminifera and Biostratigraphy of the Asmari Formation, South Yasuj, North-Central Zagros Basin, Iran. Carbonates and Evaporites, 23, 1-10. http://dx.doi.org/10.1007/BF03176247

[32] Ehrenberg, S.N., Pickard, N.A.H., Laursen, G.V., Monibi, S., Mossadegh, Z.K., Svana, T.A., Aqrawi, A.A.M., McArthur, J.M. and Thirlwall, M.F. (2007) Strontium Isotope Stratigraphy of the Asmari Formation (Oligocene-Lower Miocene), SW Iran. Journal of Petroleum Geology, 30, 107-128. http://dx.doi.org/10.1111/j.1747-5457.2007.00107.x

[33] Laursen, G.V., Monibi, S., Allan, T.L., Pickard, N.A., Hosseiney, A., Vincent, B., Hamon, Y., Van-Buchem, F.S.P., Moallemi, A. and Druillion, G. (2009) The Asmari Formation Revisited: Changed Stratigraphic Allocation and New Biozonation. First International Petroleum Conference \& Exhibition, European Association of Geoscientists and Engineers, Shiraz.

[34] Mossadegh, Z.K., Haig, D.W., Allan, T., Adabi, M.H. and Sadeghi, A. (2009) Salinity Changes during Late Oligocene to Early Miocene Asmari Formation Deposition, Zagros Mountains, Iran. Palaeogeography, Palaeoclimatology, Palaeoecology, 272, 17-36. http://dx.doi.org/10.1016/j.palaeo.2008.10.021

[35] Wynd, T. (1965) Biofacies of Iranian Oil Consortium Agreement Area. Iranian Oil Offshore Company, Report 1082.

[36] Adams, C.G. and Bourgeois, E. (1967) Asmari Biostratigraphy: Geological and Exploration Division. Iranian Oil Offshore Company, Report 1074.

[37] Tucker, M.E. and Wright, V.P. (1990) Carbonate Sedimentology. Blackwell Scientific Publications, Oxford. http://dx.doi.org/10.1002/9781444314175

[38] Lee, J.J. (1990) Fine Structure of the Rhodophycean Porphyridium purpureum in Situ in Peneroplis pertusus (Forskal) and $P$. acicularis (Batsch) and in Axenic Culture. The Journal of Foraminiferal Research, 20, 162-169. http://dx.doi.org/10.2113/gsjfr.20.2.162

[39] Allahkarampour Dill, M., Seyrafian, A. and Vaziri-Moghaddam, H. (2010) The Asmari Formation, North of the Gachsaran (Dill Anticline), SW Iran: Facies Analysis, Depositional Environment and Sequence Stratigraphy. Carbonates and Evaporites, 25, 145-160.

[40] Romero, J., Caus, E. and Rossel, J. (2002) A Model for the Palaeoenvironmental Distribution of Larger Foraminifera Based on Late Middle Eocene Deposits on the Margin of the South Pyrenean Basin (NE Spain). Palaeogeography, Palaeoclimatology, Palaeoecology, 179, 43-56. http://dx.doi.org/10.1016/S0031-0182(01)00406-0

[41] Corda, L. and Brandano, M. (2003) Aphotic Zone Carbonate Production on a Miocene Ramp, Central Apennines, Italy. Sedimentary Geology, 161, 55-70. http://dx.doi.org/10.1016/S0037-0738(02)00395-0

[42] Vaziri-Moghaddam, H., Seyrafian, A., Taheri, A. and Motiei, H. (2010) Oligocene-Miocene Ramp System (Asmari Formation) in the NW of the Zagros Basin, Iran: Microfacies, Paleoenvironmental and Depositional Sequence. Revista Mexicana de Ciencias Geológicas, 27, 56-71.

[43] Racey, A. (2001) A Review of Eocene Nummulites Accumulations: Structure, Formation and Reservoir Potential. Journal of Petroleum Geology, 24, 79-100. http://dx.doi.org/10.1111/j.1747-5457.2001.tb00662.x

[44] Brandano, M. and Corda, L. (2002) Nutrients, Sea Level and Tectonics: Constrains for the Facies Architecture of a Miocene Carbonate Ramp in Central Italy. Terra Nova, 14, 257-262. http://dx.doi.org/10.1046/j.1365-3121.2000.00419.x

[45] Pomar, L. (2001) Types of Carbonate Platforms: A Genetic Approach. Basin Research, 13, 313-334. http://dx.doi.org/10.1046/j.0950-091x.2001.00152.x

[46] Kimiagari, M. (2006) Biostratigraphy, Microfacies and Sequence Stratigraphy of the Asmari Formation in the Gurpi Anticline (Lali Area) to Khaviz Mountain (Behbahan Area). Ph.D. Thesis, Isfahan University, Isfahan, 220. (In Persian)

[47] Ghobeishavi, A. (2004) Sequence Stratigraphy of the Asmari Formation in the Khaviz Outcrop and Gachsaran Field. MSc. Thesis, Tabriz University, Tabriz.

[48] Moallemi, S.A. (2010) Depositional Environment and the Effect of Diagenetic Processes on Reservoir Characterization of the Jahrum-Asmari Formation in East of Qatar-Kazerun Fault (West of Interior Fars). Ph.D. Thesis, Shahid Beheshti University, Tehran, 400.

[49] Yazdani, R., Vaziri-Moghaddam, H., Seirafiyan, A. and Amiri Bakhtiar, H. (2007) Biostratigraphy and Depositional Environment of the Asmari Formation in the Well No. 30 of Aghajari Field. Journal of Stratigraphy and Sedimentology Researches, 25, 49-62.

[50] Pedley, M. (1996) Miocene Reef Facies of the Pelagian Region (Central Mediterranean Region). In: Franseen, E.K., Esteben, M., Ward, W.C. and Rouchy, J.M., Eds., Models for Carbonate Stratigraphy from Miocene Reef Complexes of Mediterranean Regions: SEPM Concept Sediment Paleontology, Vol. 5, 247-259. http://dx.doi.org/10.2110/csp.96.01.0247 